\title{
Streptomyces sodiiphilus sp. nov., a novel alkaliphilic actinomycete
}

\author{
Wen-Jun Li, ${ }^{1} \dagger$ Yong-Guang Zhang, ${ }^{1,2}+$ Yu-Qin Zhang, ${ }^{1}$ Shu-Kun Tang, ${ }^{1}$ \\ Ping $\mathrm{Xu}^{3}{ }^{3} \mathrm{Li}$-Hua $\mathrm{Xu}^{1}$ and Cheng-Lin Jiang ${ }^{1}$
}

Correspondence

Cheng-Lin Jiang

wjli@ynu.edu.cn or

lihxu@ynu.edu.cn

\author{
${ }^{1}$ The Key Laboratory for Microbial Resources of Ministry of Education, Yunnan Institute of \\ Microbiology, Yunnan University, Kunming, Yunnan, 650091, P. R. China \\ ${ }^{2}$ Research Centre of Industrial Microbiology, School of Biotechnology, Southern Yangtze \\ University, Wuxi, 214036, China \\ ${ }^{3}$ New Drug R \& D, North China Pharmaceutic Corp., Shijiazhuang, 050015, P. R. China
}

There are many alkaliphilic actinomycetes in highly alkaline environments, such as soda lakes and saline-alkaline lakes (Groth et al., 1997; Jones et al., 1998; Duckworth et al., 1998). Mikami et al. (1982) first reported alkaliphilic actinomycetes, and some taxonomic data and applications for alkaliphilic actinomycetes were reported subsequently (Groth et al., 1997; Duckworth et al., 1998). Alkaliphilic actinomycetes can produce many alkaline enzymes (Horikoshi, 1999) and bioactive substances, such as antibiotics (Tsujibo et al., 1988, 1990) and enzyme inhibitors (Bahn et al., 1998), and they also have typical metabolites and wide exploitation in industries.

Alkaliphilic actinomycetes that thrive in alkaline environments have typical nutrient requirements, cultural conditions and physiological properties. Up to now, there have been several reports on the physiology and energetics of alkaliphilic bacteria (Krulwich et al., 2001; Yumoto, 2002), while there are few reports on alkaliphilic actinomycetes. Thus, studies on the physiology of alkaliphilic actinomycetes

Published online ahead of print on 21 January 2005 as DOI 10.1099/ ijs.0.63457-0.

†These authors contributed equally to the work.

The GenBank/EMBL/DDBJ accession number for the 16S rRNA gene sequence of strain YIM $80305^{\top}$ is AY236339. are urgently required to exploit this microbial resource of great potential.

The effect of $\mathrm{Na}_{2} \mathrm{CO}_{3}$, which is usually used to regulate $\mathrm{pH}$ when cultivating alkaliphilic actinomycete strains, $\mathrm{NaOH}$, $\mathrm{KOH}$ and $\mathrm{K}_{2} \mathrm{CO}_{3}$ on the growth of some alkaliphilic actinomycete isolates, including strain YIM $80305^{\mathrm{T}}$, was determined. The results showed that strain YIM $80305^{\mathrm{T}}$ had special physiological characteristics; thus it was classified further using a polyphasic approach.

Strain YIM $80305^{\mathrm{T}}$ was isolated from a muddy salinealkaline soil sample collected near Chaka salt lake, Qinghai

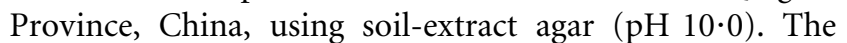
isolate was cultivated on yeast extract/malt extract agar (ISP medium 2, $\mathrm{pH} \mathrm{9.0)} \mathrm{at} 28^{\circ} \mathrm{C}$. Modified ISP medium 2 was used as basic medium for $\mathrm{pH}$ and other physiological tests; the $\mathrm{pH}$ was regulated to $\mathrm{pH} 9 \cdot 0$ by using autoclaved $\mathrm{Na}_{2} \mathrm{CO}_{3}$ and the cultivation temperature was $28^{\circ} \mathrm{C}$ unless stated otherwise. The following buffers were used: $\mathrm{pH} 6 \cdot 0$, $7 \cdot 0$ and $8 \cdot 0-0 \cdot 1 \mathrm{M} \mathrm{KH}_{2} \mathrm{PO}_{4} / 0 \cdot 1 \mathrm{M} \mathrm{NaOH} ; \mathrm{pH} 9 \cdot 0$ and $10 \cdot 0-0 \cdot 1 \mathrm{M} \mathrm{NaHCO} / 0 \cdot 1 \mathrm{M} \mathrm{Na} \mathrm{CO}_{3} ; \mathrm{pH} 11 \cdot 0-0 \cdot 05 \mathrm{M}$ $\mathrm{Na}_{2} \mathrm{HPO}_{4} / 0 \cdot 1 \mathrm{M} \mathrm{NaOH}$; and $\mathrm{pH} 12 \cdot 0-0 \cdot 2 \mathrm{M} \mathrm{KCl} / 0 \cdot 2 \mathrm{M}$ $\mathrm{NaOH}$. Strain YIM $80305^{\mathrm{T}}$ was incubated in liquid ISP medium 2 for 2-3 weeks. After the basic medium was sterilized, the $\mathrm{pH}$ was regulated to $\mathrm{pH} 6 \cdot 0,7 \cdot 0,8 \cdot 0,9 \cdot 0,10 \cdot 0$, 11.0 or 12.0 using autoclaved $\mathrm{KOH}, \mathrm{K}_{2} \mathrm{CO}_{3}, \mathrm{NaOH}$ or 
$\mathrm{Na}_{2} \mathrm{CO}_{3}$ before pouring the medium onto plates. A further test was carried out by adding $1 \cdot 0,2 \cdot 0$ or $3 \cdot 0 \%(\mathrm{w} / \mathrm{v}) \mathrm{NaCl}$ to the basic medium and the $\mathrm{pH}$ was regulated by using autoclaved $\mathrm{KOH}$ or $\mathrm{K}_{2} \mathrm{CO}_{3}$. The inoculated plates were cultivated for 2-3 weeks.

Morphological features were observed on ISP medium 2 under different conditions $(\mathrm{pH} 7 \cdot 0, \mathrm{pH} 9 \cdot 0$ and $\mathrm{pH} 9 \cdot 0$ with $3 \% \mathrm{NaCl}$ ) for 3-4 weeks with an Olympus $\mathrm{BH}-2$ microscope and by scanning electron microscopy (JSM5600LV; JEOL). Media and procedures used for cultural characteristics, physiological and biochemical features and carbon source utilization were those described by Shirling \& Gottlieb (1966) and Locci (1989), except that $\mathrm{pH}$ was regulated to $\mathrm{pH} 9 \cdot 0$ using autoclaved $\mathrm{Na}_{2} \mathrm{CO}_{3}$. Growth temperature range of strain YIM $80305^{\mathrm{T}}$ was determined on modified ISP medium $2(\mathrm{pH} \mathrm{9.0)}$ and inoculated plates were incubated at $4,10,20,28,37,45,55$ or $65^{\circ} \mathrm{C}$ for $1-2$ weeks. $\mathrm{NaCl}$ tolerance of strain YIM $80305^{\mathrm{T}}$ was determined by adding $0,3,5,7,10$ or $15 \%(\mathrm{w} / \mathrm{v}) \mathrm{NaCl}$ to the basic medium, followed by incubation for 3-4 weeks.

Cell-wall amino acids were purified and analysed by the methods of Jiang et al. (2001). The procedure of Lechevalier \& Lechevalier (1980) was used for analysis of whole-cell sugar hydrolysates. Polar lipids were extracted, examined by two-dimensional TLC and identified using published procedures (Minnikin et al., 1984). Menaquinones were determined using the procedures of Collins (1985) and separated by HPLC (Kroppenstedt, 1982). Cellular fatty acid analysis was performed as described by Sasser (1990).

The genomic DNA of strain YIM $80305^{\mathrm{T}}$ was extracted and purified by using the method of Marmur (1961). The DNA G $+C$ content of strain YIM $80305^{\mathrm{T}}$ was measured using the thermal denaturation method (Marmur \& Doty, 1962).

Extraction of genomic DNA, amplification of the $16 \mathrm{~S}$ rRNA gene and sequencing were done as described by Cui et al. (2001). Reference strains were chosen from BLAST (Altschul et al., 1997) search results. Phylogenetic analysis was performed using the software package MEGA (Molecular Evolutionary Genetics Analysis) version 2.1 (Kumar et al., 2001) after multiple alignment of data by CLUSTAL_X (Thompson et al., 1997). A phylogenetic tree was reconstructed using the neighbour-joining method of Saitou \& Nei (1987) from $K_{\text {nuc }}$ values (Kimura, 1980, 1983). The topology of the phylogenetic tree was evaluated by using the bootstrap resampling method of Felsenstein (1985) with 1000 replicates.

Morphological observation of a 21-day culture of strain YIM $80305^{\mathrm{T}}$ grown on yeast extract/malt extract agar (ISP medium 2) ( $\mathrm{pH} 9 \cdot 0$ or $\mathrm{pH} 9 \cdot 0$ with $3 \% \mathrm{NaCl}$ ) revealed that strain YIM $80305^{\mathrm{T}}$ had typical characteristics of the genus Streptomyces. Aerial mycelium and substrate mycelium were well-developed and not fragmented. Long or short chains of spores were straight to flexuous and spores were
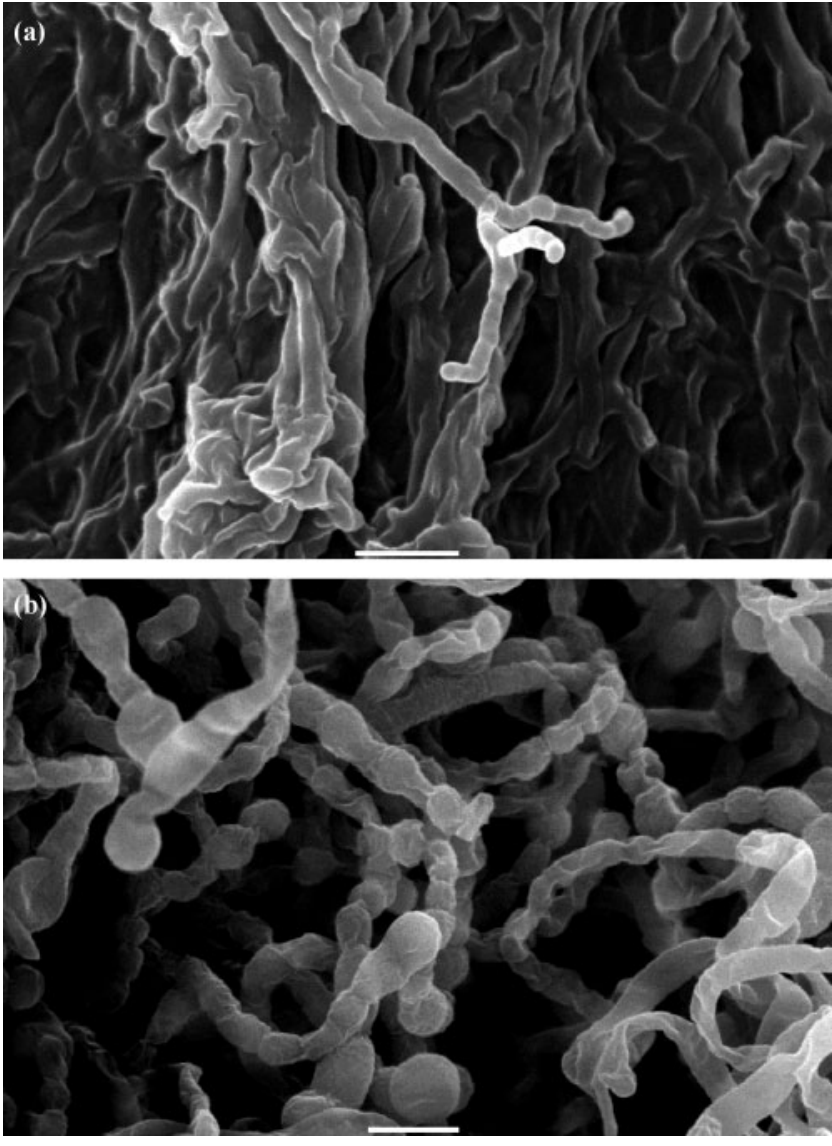

Fig. 1. Scanning electron micrographs of the spore chains of S. sodiiphilus $\mathrm{YIM} 80305^{\top}$ grown on yeast extract/malt extract agar (ISP medium 2) at $28{ }^{\circ} \mathrm{C}$ for 21 days at $\mathrm{pH} 10.0$ (a) or at $\mathrm{pH} 8 \cdot 0-9 \cdot 0$ supplemented with $5 \% \mathrm{NaCl}$ (b). Bars, $2 \mu \mathrm{m}$.

non-motile (Fig. 1). The control for strain YIM $80305^{\mathrm{T}}$ grown on ISP medium 2 at $\mathrm{pH} 7 \cdot 0$ produced very little aerial mycelium (data not shown). For cultural characteristics, strain YIM $80305^{\mathrm{T}}$ developed well on most media including Czapek's agar medium, oatmeal agar (ISP medium 3), glycerol/asparagine agar (ISP medium 5) and yeast extract/malt extract (ISP medium 2). It showed poor growth on nutrient agar. No growth was observed on inorganic salt/starch agar (ISP medium 4). No diffusible pigments were produced except on nutrient agar medium (pale orange-yellow).

The cell wall of strain YIM $80305^{\mathrm{T}}$ contained LL-diaminopimelic acid and glycine, indicating that strain YIM $80305^{\mathrm{T}}$ was of chemotype I (Lechevalier \& Lechevalier, 1970a, b). The whole-cell hydrolysates mainly contained galactose and glucose but no diagnostic sugars. The predominant menaquinones were MK-9 $\left(\mathrm{H}_{4}\right)(13 \%)$, MK-9 $\left(\mathrm{H}_{6}\right)(68 \%)$ and MK-9 $\left(\mathrm{H}_{8}\right)(19 \%)$, and the diagnostic phospholipid was phosphatidylethanolamine. The major fatty acid components were ai- $\mathrm{C}_{15: 0}(16 \cdot 47 \%)$, ai- $\mathrm{C}_{17: 0}(13 \cdot 30 \%)$ and i- $\mathrm{C}_{16: 0}(31 \cdot 32 \%)$. Thus, chemotaxonomic and phenotypic 
Table 1. Influence of different alkaline compounds on the growth of strain YIM $80305^{\top}$

$\mathrm{Na}_{2} \mathrm{CO}_{3}$ showed no obvious effect on the growth of YIM $80305^{\mathrm{T}}$ at $\mathrm{pH} 7 \cdot 0-12 \cdot 0$. Symbols: +, growth; - , no growth.

\begin{tabular}{|lcccccc|}
\hline Compound & \multicolumn{7}{c|}{$\mathbf{p H}$} \\
\cline { 2 - 7 } & $\mathbf{7 \cdot 0}$ & $\mathbf{8 \cdot 0}$ & $\mathbf{9 \cdot 0}$ & $\mathbf{1 0 \cdot 0}$ & $\mathbf{1 1 \cdot 0}$ & $\mathbf{1 2 \cdot 0}$ \\
\hline $\mathrm{KOH}$ & + & + & - & - & - & - \\
$\mathrm{K}_{2} \mathrm{CO}_{3}$ & + & + & - & - & - & - \\
$\mathrm{NaOH}$ & + & + & + & + & + & - \\
\hline
\end{tabular}

data showed that strain YIM $80305^{\mathrm{T}}$ should be assigned to the genus Streptomyces.

Strain YIM $80305^{\mathrm{T}}$ could grow between $\mathrm{pH} 7 \cdot 0$ and $12 \cdot 0$, and its optimal pH was $9 \cdot 0-10 \cdot 0 . \mathrm{KOH}, \mathrm{K}_{2} \mathrm{CO}_{3}, \mathrm{NaOH}$ and $\mathrm{Na}_{2} \mathrm{CO}_{3}$ had different effects on its growth (Table 1). $\mathrm{KOH}$ and $\mathrm{K}_{2} \mathrm{CO}_{3}$ showed obvious inhibition of the growth of strain YIM $80305^{\mathrm{T}}$, and it only grew at $\mathrm{pH} 7 \cdot 0-8 \cdot 0$ with them, while $\mathrm{NaOH}$ and $\mathrm{Na}_{2} \mathrm{CO}_{3}$ showed no obvious effect on growth. However, when 1,2 or $3 \% \mathrm{NaCl}$ was added to the basic medium using $\mathrm{KOH}$ and $\mathrm{K}_{2} \mathrm{CO}_{3}$ to regulate $\mathrm{pH}$, the $\mathrm{pH}$ range for the growth of YIM $80305^{\mathrm{T}}$ was increased: it grew at $\mathrm{pH} 7 \cdot 0-11 \cdot 0$ when using $\mathrm{KOH}$ and at $\mathrm{pH} 7 \cdot 0-9 \cdot 0$ with $\mathrm{K}_{2} \mathrm{CO}_{3}$. Small amounts of $\mathrm{NaCl}$ could promote the growth of YIM $80305^{\mathrm{T}}$. It was interesting that strain YIM $80305^{\mathrm{T}}$ showed a wider $\mathrm{pH}$ range for growth on the basic medium using $\mathrm{KOH}$ than that using $\mathrm{K}_{2} \mathrm{CO}_{3}$ when adding $1 \cdot 0,2 \cdot 0$ or $3 \cdot 0 \% \mathrm{NaCl}$. All the results showed that YIM $80305^{\mathrm{T}}$ was obligately dependent on $\mathrm{Na}^{+}$, especially in highly alkaline media, but that it showed sensitivity to $\mathrm{K}^{+}$in highly alkaline media. The optimum growth temperature and $\mathrm{NaCl}$ concentration are $28{ }^{\circ} \mathrm{C}$ and $3 \%(\mathrm{w} / \mathrm{v})$, respectively.

The almost-complete 16S rRNA gene sequence (1489 nt) for the novel strain was aligned manually with corresponding almost-complete sequences of representative Streptomyces species retrieved from the GenBank, EMBL and DDBJ databases by using BLAST (Altschul et al., 1997). Phylogenetic analyses based on a dataset consisting of 1452 unambiguous nucleotides at positions 45 to 1496 (Escherichia coli numbering; Brosius et al., 1978) showed that the novel isolate falls into one distinct subclade with two other species, Streptomyces albus subsp. albus (GenBank/EMBL/DDBJ accession no. AJ621602) (97.6\% sequence similarity) and Streptomyces armeniacus (GenBank/EMBL/DDBJ accession no. AB018094) (96.0\% sequence similarity). The phylogenetic tree based on the 16S rRNA gene sequences of strain YIM $80305^{\mathrm{T}}$ and the most closely related type strains of the genus Streptomyces is shown in Fig. 2.

The variable $\gamma$ region sequences (positions 158 to 277) of the 16S rRNA gene from 452 known Streptomyces species obtained from the DDBJ databases and from strain YIM $80305^{\mathrm{T}}$ were aligned. Analysis of $\gamma$ region sequences showed that strain YIM $80305^{\mathrm{T}}$ was grouped into a branch with



Fig. 2. Phylogenetic tree based on $16 \mathrm{~S}$ rRNA gene sequences showing the positions of YIM $80305^{\top}$ and related strains. Only bootstrap values above $50 \%$, expressed as percentages of 1000 replications, are shown at the branch points. Bar, 0.01 substitution per nucleotide position. 
strains of recognized Streptomyces species, including Streptomyces rimosus ISP $5260^{\mathrm{T}}$, Streptomyces ochraceiscleroticus ISP $5594^{\mathrm{T}}$, Streptomyces olivaceus JCM 4066, Streptomyces violens ISP $5597^{\mathrm{T}}$, Streptomyces purpurogeneiscleroticus ISP $5271^{\mathrm{T}}$ and Streptomyces niger ISP $5302^{\mathrm{T}}$. Although strain YIM $80305^{\mathrm{T}}$ had almost the same sequence of the variable $\gamma$ region as those strains, it had broad phenotypic differences (Table 2). The renaturation rates of genomic fragments from pairs of strains were determined spectrophotometrically with a model 1601 UV spectrophotometer equipped with a Thermoelectric Cell Temperature Controller (Shimadzu) according to the previously described methods (De Ley et al., 1970; Huss et al., 1983), and the low DNA-DNA relatedness (all below $40 \%$ ) between strain YIM $80305^{\mathrm{T}}$ and the related type strains also confirmed that they are different genomic species.

Thus, polyphasic data show that strain YIM $80305^{\mathrm{T}}$ represents a novel species of the genus Streptomyces, for which we propose the name Streptomyces sodiiphilus sp. nov.

\section{Description of Streptomyces sodiiphilus sp. nov.}

Streptomyces sodiiphilus (so.di.i' phi.lus. N.L. n. sodium -i; Gr. adj. philos loving; N.L. adj. sodiiphilus sodium ion-loving, referring to the characteristic of $\mathrm{Na}^{+}$-dependent growth).
Aerobic and Gram-positive. Both vegetative and aerial hyphae are well-developed and not fragmented. Long or short chains of spores are straight to flexuous and spores are non-motile. No diffusible pigments are produced except on nutrient agar medium (pale orange-yellow). Sodium acetate and rhamnose can be used as sole carbon sources for growth, but not most other carbon sources, such as lactose, maltose, fructose, xylose, ribose, arabinose, sucrose, glucose, galactose, sodium citrate, cellobiose, cellubinose, raffinose, mannitol, sorbitol, glycerol and starch. Positive for gelatin liquefaction and nitrate reduction, but negative for urease, melanin production, starch hydrolysis, $\mathrm{H}_{2} \mathrm{~S}$ production, milk coagulation and milk peptonization. Cell wall contains LL-diaminopimelic acid and glycine. Whole-cell hydrolysates mainly contain galactose and glucose and no diagnostic sugars. Predominant menaquinones are MK-9 $\left(\mathrm{H}_{4}\right)$ (13\%), MK-9 $\left(\mathrm{H}_{6}\right) \quad(68 \%)$ and MK-9 $\left(\mathrm{H}_{8}\right) \quad(19 \%)$, and the diagnostic phospholipid is phosphatidylethanolamine. Major fatty acid components are ai- $\mathrm{C}_{15: 0}(16 \cdot 47 \%)$, ai$\mathrm{C}_{17: 0}(13 \cdot 30 \%)$ and $\mathrm{i}-\mathrm{C}_{16: 0}(31 \cdot 32 \%)$. Grows optimally at $28^{\circ} \mathrm{C}$ and in ISP medium 2 with $3 \% \mathrm{NaCl}$ and $\mathrm{pH} 9 \cdot 0-10 \cdot 0$. DNA G $+\mathrm{C}$ content is $70 \cdot 5 \mathrm{~mol} \%$.

The type strain, YIM $80305^{\mathrm{T}}\left(=\right.$ CCTCC AA $203015^{\mathrm{T}}=$ CIP $\left.107975^{\mathrm{T}}\right)$, was isolated from a soil sample collected from Chaka salt lake, Qinghai Province, China.

Table 2. Phenotypic properties that separate strain YIM $80305^{\top}$ from most-related Streptomyces species based on analyses of almost-complete and variable $\gamma$ region $16 \mathrm{~S}$ rRNA gene sequences

Strains: 1, YIM $80305^{\mathrm{T}}$; 2, S. rimosus ISP $5260^{\mathrm{T}}$; 3, S. ochraceiscleroticus JCM $4801^{\mathrm{T}}$, ISP $5594^{\mathrm{T}}$; 4, S. olivaceus JCM 4066; 5, S. violens ISP $5597^{\mathrm{T}}$; 6, S. purpurogeneiscleroticus ISP $5271^{\mathrm{T}}$; 7, S. niger ISP $5302^{\mathrm{T}} ; 8$, S. albus subsp. albus DSM 40313 ${ }^{\mathrm{T}}$; 9 , S. armeniacus JCM $3070^{\mathrm{T}}$. Abbreviations: R, red; G, grey; GW, grey-white; Y, yellow; W, white; S, smooth; WS, wrinkled surface; ST, straight; RA, Retinaculiaperti; RF, Rectiflexibiles; SP, Spirales. Symbols: +, utilized; -, not utilized; V, variable; d, doubtful; ND, not determined. For S. violens ISP $5597^{\mathrm{T}}$, aerial mycelium was absent on yeast extract/malt extract agar (ISP medium 2), oatmeal agar, inorganic salt/starch agar and glycerol/ asparagine agar, and thus no spore was borne; see Shirling \& Gottlieb (1972). Data for reference type strains were taken from Shirling \& Gottlieb (1968, 1969, 1972).

\begin{tabular}{|c|c|c|c|c|c|c|c|c|}
\hline Characteristic & 1 & 2 & 3 & 4 & 5 & 6 & 7 & 8 \\
\hline Colony colour on ISP medium 2 & GW & $\mathrm{R}$ to $\mathrm{W}$ & $\mathrm{Y}$ & G & - & $\mathrm{W}$ & GW & $\mathrm{W}$ or $\mathrm{Y}$ \\
\hline Spore surface & WS & $S$ & S & S & - & $\mathrm{S}$ & S & S \\
\hline Spore-chain morphology & ST to RA & SP to RA & SP & $\mathrm{RF}$ & - & SP & SP & SP \\
\hline Production of diffusible pigment & + & - & $\mathrm{V}$ & - & - & + & $\mathrm{V}$ & - \\
\hline Melanoid pigment & + & - & - & - & - & - & - & - \\
\hline \multicolumn{9}{|l|}{ Utilization of: } \\
\hline Glucose & - & + & + & + & + & + & + & + \\
\hline Arabinose & - & + & + & + & + & + & + & $\mathrm{V}$ \\
\hline Mannitol & - & + & + & + & + & + & + & + \\
\hline Fructose & - & + & + & + & + & + & + & + \\
\hline Rhamnose & + & - & + & + & + & + & + & - \\
\hline Sucrose & - & $\mathrm{V}$ & + & $\mathrm{V}$ & + & + & + & - \\
\hline Raffinose & - & + & + & $\mathrm{V}$ & + & + & + & V \\
\hline Inositol & - & + & + & + & + & + & + & - \\
\hline Xylose & - & $\mathrm{D}$ & + & + & + & + & + & + \\
\hline
\end{tabular}




\section{Acknowledgements}

This research was supported by National Basic Research Program of China (project no. 2004CB719601), National Natural Science Foundation of China (project no. 30270004) and Yunnan Provincial Natural Science Foundation (project no. 2004 C0002Q).

\section{References}

Altschul, S. F., Madden, T. L., Schaffer, A. A., Zhang, J., Zhang, Z., Miller, W. \& Lipman, D. J. (1997). Gapped BLAST and PSI-BLAST: a new generation of protein database search programs. Nucleic Acids Res 25, 3389-3402.

Bahn, Y. S., Park, J. M., Bai, D. H., Takase, S. \& Yu, J. H. (1998). YUA001, a novel aldose reductase inhibitor isolated from alkalophilic Corynebacterium sp. YUA25. I. Taxonomy, fermentation, isolation and characterization. J Antibiot (Tokyo) 51, 902-907.

Brosius, J., Palmer, M. L., Kennedy, P. J. \& Noller, H. F. (1978). Complete nucleotide sequence of a $16 \mathrm{~S}$ ribosomal RNA gene from Escherichia coli. Proc Natl Acad Sci U S A 75, 4801-4805.

Collins, M. D. (1985). Isoprenoid quinone analysis in classification and identification. In Chemical Methods in Bacterial Systematics, pp. 267-287. Edited by M. Goodfellow \& D. E. Minnikin. London: Academic Press.

Cui, X.-L., Mao, P.-H., Zeng, M., Li, W.-J., Zhang, L.-P., Xu, L.-H. \& Jiang, C.-L. (2001). Streptimonospora salina gen. nov., sp. nov., a new member of the family Nocardiopsaceae. Int J Syst Evol Microbiol 51, 357-363.

De Ley, J., Cattoir, H. \& Reynaerts, A. (1970). The quantitative measurement of DNA hybridization from renaturation rates. Eur J Biochem 12, 133-142.

Duckworth, A. W., Grant, S., Grant, W. D., Jones, B. E. \& Meijer, D. (1998). Dietzia natronolimnaios sp. nov., a new member of the genus Dietzia isolated from an East African soda lake. Extremophiles 2, 359-366.

Felsenstein, J. (1985). Confidence limits on phylogenies: an approach using the bootstrap. Evolution 39, 783-791.

Groth, I., Schumann, P., Rainey, F. A., Martin, K., Schuetze, B. \& Augsten, K. (1997). Bogoriella caseilytica gen. nov., sp. nov., a new alkaliphilic actinomycete from a soda lake in Africa. Int $J$ Syst Bacteriol 47, 788-794.

Horikoshi, K. (1999). Alkaliphiles: some applications of their products for biotechnology. Microbiol Mol Biol Rev 63, 735-750.

Huss, V. A. R., Festl, H. \& Schleifer, K. H. (1983). Studies on the spectrophotometric determination of DNA hybridization from renaturation rates. Syst Appl Microbiol 4, 184-192.

Jiang, L.-Y., Li, M.-G., Li, W.-J., Cui, X.-L., Xu, L.-H. \& Jiang, C.-L. (2001). Study on the application of quantitative analysis of cell-wall amino acids in actinomycetes classification. Wei Sheng Wu Xue Bao 41, 270-277 (in Chinese).

Jones, B. E., Grant, W. D., Duckworth, A. W. \& Owenson, G. G. (1998). Microbial diversity of soda lakes. Extremophiles 2, 191-200.

Kimura, M. (1980). A simple method for estimating evolutionary rates of base substitutions through comparative studies of nucleotide sequences. J Mol Evol 16, 111-120.

Kimura, M. (1983). The Neutral Theory of Molecular Evolution. Cambridge: Cambridge University Press.

Kroppenstedt, R. M. (1982). Separation of bacterial menaquinones by HPLC using reverse phase (RP 18) and a silver loaded ion exchanger as stationary phases. J Liquid Chromatogr 5, 2359-2387.

Krulwich, T. A., Ito, M. \& Guffanti, A. A. (2001). The $\mathrm{Na}^{+}$-dependence of alkaliphily in Bacillus. Biochim Biophys Acta 1505, 158-168.
Kumar, S., Tamura, K., Jakobsen, I. B. \& Nei, M. (2001). MEGA2: molecular evolutionary genetics analysis software. Bioinformatics $\mathbf{1 7}$, 1244-1245.

Lechevalier, H. A. \& Lechevalier, M. P. A. (1970a). Critical evaluation of the genera of aerobic actinomycetes. In The Actinomycetes, pp. 393-405. Edited by H. Prauser. Jena: Gustav Fischer Verlag.

Lechevalier, M. P. \& Lechevalier, H. A. (1970b). Chemical composition as a criterion in the classification of aerobic actinomycetes. Int J Syst Bacteriol 20, 435-443.

Lechevalier, M. P. \& Lechevalier, H. A. (1980). The chemotaxonomy of actinomycetes. In Actinomycete Taxonomy, pp. 22-291. Edited by A. Dietz \& D. W. Thayer. Arlington, VA: Society for Industrial Microbiology.

Locci, R. (1989). Streptomycetes and related genera. In Bergey's Manual of Systematic Bacteriology, vol. 4, pp. 2451-2508. Edited by S. T. Williams, M. E. Sharpe \& J. G. Holt. Baltimore: Williams \& Wilkins.

Marmur, J. (1961). A procedure for the isolation of deoxyribonucleic acid from microorganisms. J Mol Biol 3, 208-218.

Marmur, J. \& Doty, P. (1962). Determination of the base composition of deoxyribonucleic acid from its thermal denaturation temperature. J Mol Biol 5, 109-118.

Mikami, Y., Miyashita, K. \& Arai, T. (1982). Diaminopimelic acid profiles of alkalophilic and alkaline-resistant strains of actinomycetes. J Gen Microbiol 128, 1709-1712.

Minnikin, D. E., O’Donnell, A. G., Goodfellow, M., Alderson, G., Athalye, M., Schaal, A. \& Parlett, J. H. (1984). An integrated procedure for the extraction of isoprenoid quinines and polar lipids. J Microbiol Methods 2, 233-241.

Saitou, N. \& Nei, M. (1987). The neighbor-joining method: a new method for reconstructing phylogenetic trees. Mol Biol Evol 4, 406-425.

Sasser, M. (1990). Identification of bacteria by gas chromatography of cellular fatty acids. USFCC Newsl 20, 16.

Shirling, E. B. \& Gottlieb, D. (1966). Methods for characterization of Streptomyces species. Int J Syst Bacteriol 16, 313-340.

Shirling, E. B. \& Gottlieb, D. (1968). Cooperative description of type cultures of Streptomyces. II. Species descriptions from the first study. Int J Syst Bacteriol 18, 69-189.

Shirling, E. B. \& Gottlieb, D. (1969). Cooperative description of type cultures of Streptomyces. IV. Species descriptions from the second, third and fourth studies. Int J Syst Bacteriol 19, 391-512.

Shirling, E. B. \& Gottlieb, D. (1972). Cooperative description of type cultures of Streptomyces. V. Additional descriptions. Int J Syst Bacteriol 22, 265-394.

Thompson, J. D., Gibson, T. J., Plewniak, F., Jeanmougin, F. \& Higgins, D. G. (1997). The CLUSTAL_X windows interface: flexible strategies for multiple sequence alignment aided by quality analysis tools. Nucleic Acids Res 25, 4876-4882.

Tsujibo, H., Sato, T., Inui, M., Yamamoto, H. \& Inamori, Y. (1988). Intracellular accumulation of phenazine antibiotics produced by an alkalophilic actinomycete. I. Taxonomy, isolation and identification of the phenazine antibiotics. Agric Biol Chem 52, 301-306.

Tsujibo, H., Sakamoto, T., Miyamoto, K., Kusano, G., Ogura, M., Hasegawa, T. \& Inamori, Y. (1990). Isolation of cytotoxic substance, kalafungin from an alkalophilic actinomycete, Nocardiopsis dassonvillei subsp. prasina. Chem Pharm Bull (Tokyo) 38, 2299-2300.

Yumoto, I. (2002). Bioenergetics of alkaliphilic Bacillus spp. J Biosci Bioeng 93, 342-353. 